GOMBOS Péter

MATE Neveléstudományi Intézet

Anyanyelvi és Gyermekkultúra Tanszék

ORCID: 0000-0002-8172-0557

gombos.peter@uni-mate.hu

\section{A keresztény gyermekirodalom és a humor}

Miközben tanulmányomban konkrét szerzőket, sőt szövegeket is bemutatok, alapjában véve elméleti kérdéseket vetek fel s próbálok megválaszolni.

Mi az, hogy keresztény irodalom? Mi az, hogy keresztény gyermekirodalom? Van-e, lehete helye a didaxisnak a (keresztény) gyermekirodalomban? Van létjogosultsága a humornak a keresztény irodalomban?

A fogalmak és az alapkérdések tisztázása után nem bocsátkoztam a szóba jöhető művek felosztásába, csoportosításába. Legfóképpen azért nem, mert a témán belül - különösen magyar szerzóket figyelembe véve - nincs annyiféle müfaj, s arányaiban a müvek száma sem jelentős, hogy ennek relevanciája lenne. Hogy mégsem érzem indokolatlannak magát a témafelvetést, az elsősorban az elmúlt évtizedek tapasztalatainak köszönhető. Miközben az indulás kifejezetten nehéz volt - az irodalmi értékek sokáig maximum „átsejlettek” a didaktikus szövegek mögül -, a jelen több mint biztató. A keresztény gyermekirodalom "fejlődése” mintha párhuzamosan, együtt menne a gyermekirodalom haladásával.

Kulcsszavak: gyermekirodalom, keresztény irodalom, humor

Bár az obligát kérdés a címben lévő két fogalom kapcsán fogalmazódhat meg bennünk van-e s hol lehet létjogosultsága a humornak a keresztény gyermekirodalomban -, mindenekelőtt fontos meghatároznunk, mit értünk 'gyermekirodalmon', illetve 'keresztény gyermekirodalmon'.

Komáromi Gabriellával egyetértve valljuk, hogy a gyermekirodalom csak a befogadó felől értelmezhető (Komáromi 1999), nem poétikai-narratológiai vagy nyelvi, pláne nem didaktikai szempontból kell keresni a megkülönböztető jegyeket. Vagyis azok az irodalmi művek tartoznak ide, amelyek a kicsik számára valamiért érdekesek. A „miért” néha nem is megfejthető. Lehet ok - s ez gyakran így van - a cselekmény, a kaland(osság), de versek esetében még inkább a hangzás, a ritmus.

Látszólag egyértelmű a szúkítés a keresztény jelzővel, valójában azonban egyáltalán nem egyszerű a helyzet, mármint a keresztény és más célú (ifjúsági) irodalom szétválasztása. Nem segít a történelmi hagyomány sem, amelynek hatása még mindig kimutatható a gyermekkönyveknél:

„A XX. század közepéig a vallásos gyermekkönyvek az iskolai (hittan)oktatás eszközei voltak, szerzőik elsődlegesen nem irodalmi, hanem hitbeli és pedagógiai szempontokat tartottak szem előtt. Az iskolai tankönyvek olvasmányai, a versekbe szedett viselkedési 
szokások, imádságok és bibliai történetek a vallásos tradíció reformáció koráig nyúló hagyományait követték, szerzőik pedagógusok, lelkészek voltak, akik nagy jóindulattal, de kevés tehetséggel bírtak, így vált a gyermekirodalom a vallás és a pedagógia szolgálólányává. A romantika kora, a népmesék felfedezése, Andersen meséinek magyar fordítása (1856) és az önálló műmese-irodalom létrejötte az a fordulópont, amikor különválnak a vallásos és a világi gyermekolvasmányok." (Pompor 2009, 21)

Fontos leszögeznünk tehát, hogy a keresztény könyv nem ekvivalens a keresztény irodalommal. Irodalmat más szemmel, más lélekkel, más szívvel olvasunk, mint ismeretterjesztő szöveget, más a céljuk is e műveknek. Nem véletlen, hogy a keresztény könyvek többsége alighanem ma is teológiai jellegü írás. A szépirodalom kategóriájába sorolható keresztény könyvek száma - különösen a magyar szerzők tollából születetteké - nem is túl nagy. Nyilván sok oka van ennek, de kevés író (még kevesebb jó író) érzett késztetést arra, hogy hitéről egy szépirodalmi műben tegyen bizonyságot. Talán a legfőbb ok az, hogy a szándékoltan tanító, nevelő szándékkal írott regények, versek (akart, akarjon az tanítani a kereszténységről, a jó viselkedésről vagy épp a szocializmus/kommunizmus vagy épp a fasizmus dicsőséges jelenéről/jövőjéről) irodalmi szempontból halva született ötletnek számítanak. Ahogy Esterházy Péter fogalmazott: „...nem jó példát mutatni van az irodalom. [...] Nem arra van, hogy tanítson, neveljen, szórakoztasson. Nem »alkalmazott tudomány«. A szépség vad és szelídíthetetlen.” (Esterházy 2003, 29)

Drescher Pál már 1934-ben (!) így írt erről: „a mai gyermek megmosolyogná azt az olvasmányt, melyből az irányzatosság ennyire kirí. Miként a mai gyermek előtt ellenszenvesek ezek a jámbor tanulságokkal telitüzdelt, elbeszélő köntösbe öltöztetett párbeszédes erkölcs-értekezések s ezek az egy kaptafára húzott érdektelen, élettelen alakok..." (Drescher 1934)

Az idők során tehát kiderült, a propagandairodalom, szóljon bármilyen eszme, nézet, irányzat mellett, agitációnak jó lehet, irodalomnak nem. Bár a jóra nevelés szándéka - $s$ ezzel együtt a jóra tanítani akaró „írók” száma - aligha csökkent az elmúlt évtizedekben, a didaktikai célzatú írások továbbra sem tekinthetők a szépirodalom részének. Ennek a vakbuzgó, jó szándékú igyekezetnek egyébként részben történelmi hagyományai is vannak Európában. Ha csak a magyar gyerekek számára készült könyvek történetét megnézzük, az első 300 év „termése” túlnyomórészt tankönyvekből és tanító szándékú írásokból áll.

Megint Dreschert idézve: „Nem végzetes túlzás-e az, hogy 11-12 éves gyermekeink könyvébe ótestamentomi történetek közé archeológiát csempészünk s a bibliai csodákat természettudományos magyarázatokkal »tarkítjuk«, tesszük »érthetőbbé«? [...]

Nem sodródik-e szükségképp Istentől s a világ édes csodálatától el s szegény kis orosz pajtása sorsára, kinek a beléjevert egyedül üdvözítő "gazdasági« világszemlélet erejénél fogva az erdő minden szépsége és titokzatossága előtt szemet kell hunynia (a fészek-fosztás öröméről nem is szólván) s csak fa-kitermelési eshetőségeket szabad mérlegelnie?

Ó, ne józanítsuk, ne okosítsuk annyira túl gyermekeinket!

Hagyjuk meg bennük az ösztönszerűség, a spontanitás erőteljes mozdulatát; az élet ősi (elsődleges) örömeit s vídám frissességét; a hit hamvát s a csodálkozás isteni adományát; a természetközelség egyszerüségét." (Drescher 1934)

Ez már-már programszerű kérés, felszólítás. Ráadásul olyan, amely nagyjából két évtizeddel meghaladta a korát. Mert arra a cezúrára, amely után - legalább már a gyermekeknek írók körében - nem volt népszerű sem a gügyögés, gagyogás, sem az explicit didaktikusság, még majdnem húsz évet várni kellett. Weöres Sándor Bóbitája hozta meg ezt a váltást, amely évtizedek múltán, máig is érezteti hatását e téren. Az Ifjúsági (későbbi 
nevén Móra) Kiadó főszerkesztője, Kormos István egyértelműen az ő (gyermekirodalomban) megjelenését jelölte meg a változás kezdetének. Sőt, az elődök műveit nem egyszerűen gyengének, de méltatlannak is érezte Weöres - eredendően nem is kicsiknek írt verseihez mérve:

„Pósa bácsi és utódai vígan lubickoltak »költészetük« békalencsés állóvizében, s nemzedékek fejét - gyanútlan gyerekfejeket - nyomták az undok lé alá, kortyoltatván belőle nagyokat, $\mathrm{s}$ a gyerekek ittak, nem lévén más italuk. Jobb nem gondolni gyerekköltészetünk őskorára - ennyi a története." (Kormos 1982, 156)

Ha a korszak meghatározó - nem utolsósorban: egy ideig egyedüli - gyermekkönyvkiadójának vezetője ilyen következetesen elhatárolódott a didaxistól és a „gügyögéstől”, azt gondolhatjuk, hogy a magyar gyerekkönyvekben ritkán találkozhattunk ilyen szándékkal, motívummal. De ez éppúgy nem igaz, sajnos, ahogy a korszak keresztény ifjúsági művei is sokkal direktebben próbáltak „hatni”, mint amennyire az irodalomban ez elviselhető. Magyar szerzőktől persze nem találunk példát - esélye sem volt ilyen tematika megjelenésének az ifjúsági irodalomban az 1950-60-as években -, de Patricia M. St. John müvei vagy épp C. S. Lewis első Narnia-könyvének eredeti utószava jól mutatják: még a jó szerzők is féltek a gyerekre bízni, felismerik-e a bibliai tanítást, így aztán az ízlésesnél szájbarágósabb motívumok terhelik a szövegeket.

Mindezt látva már az is felmerülhet, létezik, létezhet egyáltalán „jó, keresztény irodalom"? Olyan, amely elsősorban irodalom, amely éppen ezért nem akar tanítani. Visszatértünk az eredeti felvetéshez, a fogalom meghatározásához. Talán nem véletlen, hogy szinte még próbálkozást sem látunk definícióalkotásra a témában... (Pompor 2009) Hiszen ha feltételezünk írói szándékot - vagyis megjelenik a didaxis -, akkor ez máris kizárja, de legalábbis minimálisra csökkenti az irodalmi értéket.

Érdemes két érintett szerző véleményét megismerni minderről. R. K. Alker angol író így vall egy népszerűvé vált könyve kapcsán: „Az volt a célom, hogy írjak egy vidám, keresztény gyerekkönyvet? Nem. A célom egy vidám gyerekköny (képeskönyv) megírása volt..." (Alker 2019)

Egy másik nehézségre világít rá a kiváló költő, Miklya Zsolt: „....szerkesztőként ma már nem a dilettáns kéziratoktól félek a legjobban [...], hanem a kifejezetten jó szövegektől, mert ezek többnyire túljutottak a direkt módon didaktikus megközelítésen és formákon, képesek élményt adni, s ezen keresztül hatni, ami azért veszélyes, mert az olvasó nem feltétlenül azt a következtetést fogja levonni belőle, ami a nagykönyvben vagy a hitvallásokban meg van írva." (Miklya 2009, 19)

Egyre bonyolultabb a helyzet. Az lehet végül jó, keresztény irodalom, amely nem akar kereszténynek mutatkozni?! Igen, nem kell attól félnünk, hogy olyan szerzők között keressük a bibliai tanítást hitelesen képviselőket, akik sosem kérkedtek ezzel, s a műveik sem kaptak erre utaló címkét. Lázár Ervin szinte minden írásában kulcsszó a szeretet, de van kvázi tanúságtévő novellája is - a Foci című. S hogy még merészebb példát hozzak: számomra kevés, a keresztény értékeket hitelesebben képviselő regénysorozat van Görgey Eta sci-fijénél (!), a Csodaidőknél.

S ha hasonló külföldi példát keresünk: érthetetlenül kevesen beszélnek arról, hogy Felix Salten Bambija olyan fejlődésregény, amelynek címszereplője akkor érik meg az erdő hercegi címére, amikor kimondja a keresztény alapvetést: „Valaki más van mindnyájunk fölött... mifölöttünk és Őfelette." Vagyis nem az ember (Ő) a mindenható. Ha pontos meghatározást szeretnénk, inkább csak azt jelölhetjük meg, mi nem lehet keresztény (gyermek)irodalom: az, ami ellentmond a Biblia tanításának. 
Humorról még nem esett szó, „csak” azt tisztáztuk (nagyjából), hogy a keresztény gyermekirodalom terminust érdemes tágabb értelemben használni. A kérdés azonban így is nagyon adja magát: összeférhet az élet értelméről, az élet utáni lét kérdéséről gyakran beszélő vallás (még nem az ehhez így-úgy kapcsolódó irodalom) a derűvel? Az a vallás, amelynek fontos tanítása, hogy Isten fia kínhalált szenvedett mások megváltásáért. Ha azt állítanánk, hogy a Biblia gyakran él a humor eszközével, aligha mondanánk igazat. De legalább akkora tévedés lenne azt gondolni, hogy a Szentírástól idegen volna a derű, az irónia, a humor. Hogy konkrét példát hozzak: Izajás (Ézsaiás) prófétánál az Úristen egy alkalommal azt mondja az embereknek, hogy ő jogőrzésre várt, és lett jogorzás, várt irgalomra, és lett siralom. A Szentírás-fordítások közül talán csak a magyar próbálkozott meg azzal, hogy visszaadja az eredeti héber szöveg szójátékát. Miszfat-mispat, cödáká-cöáká. Kis online keresgéléssel hosszas elemzésekre, példagyűjteményekre bukkanhatunk a „Biblia humora”, „Jézus humora” kulcsszavakkal. Szójátékok, helyzetkomikumok, nyelvi humor mindre van precedens a Szentírásban, s tényleg nem erőltetettek a példák.

Ha a tanítások könyvénél „belefér” ez, a keresztény (gyermek)irodalomnál annál inkább - gondolhatjuk. Ám be kell látnunk, az igazi humor jellemzően csupán az elmúlt évtizedekben jelent meg e tematikában. De ezúttal is igaz a ,jobb késő" bölcsessége, mert a példák azt mutatják, kifejezetten jól áll a műfajnak az önirónia vagy éppen a derű.

Ha már az előbbi fogalom előkerült, megkerülhetetlen Adrian Plass Kegyes kétbalkezes-sorozata. Miközben a szerző egészen komoly regényeket is írt (többek között Bibliakommentárok mellett), a világhírt önironikus hőse hozta meg neki. „Nagyon »jó keresztyén lennék «, ha időnként nem zavarnák meg mások az életemet" - írja esendő, meg-megbotló hősünk, aki emberi gyengeségével nem szánalmat, inkább szimpátiát vált ki olvasójából. De be kell látnunk, ha nem lennénk túl már évtizedekkel a nagy antiautoriter hullámon az ifjúsági irodalomban, ha nem ismernénk már ötven éve a „svéd gyerekverset” mint műfajt, talán nem mernénk ilyen jóízűen nevetni a „kegyes kétbalkezesen” - s vele együtt magunkon...

A magyar keresztény ifjúsági irodalomban Kamarás István nevét kell először megemlítenünk, ha azt az írót keressük, akitől távol áll a tanító szándék, ugyanakkor az eszköztárában mindig ott van a humor. Nála a Jóisten akár szájharmonikázhat is (hamisan, mert tehetsége nagy részét Bachnak adományozta...) - lásd a Csigamesét.

Ha pedig a fentebb már emlegetett „svéd gyerekversek” műfajára gondolunk, itt is van magyar érintettség. Régóta tudjuk, hogy a weöresi hagyományt szívesen továbbéltető ritmikus gyermeklíra mellett kifejezetten erős a gyermeki hangon megszólaló, szókimondásáról is híres, úgynevezett „svéd típusú” költészetünk is. Ágai Ágnes, Csorba Piroska, Kiss Ottó után, mellett Miklya Zsolt neve is jól cseng, sőt kihagyhatatlan e felsorolásból. Különösen akkor, ha a témaválasztására is figyelemmel leszünk. Miklyának két olyan gyermekverses kötete is van ugyanis, amelyben a vallás, a hit, az Isten-kép kulcs-fontosságú. „Az Ezüstszín fonál kétféle vallásos gyermekvers-típusa példa a tradíció elfogadására és felülírására, hiszen a hagyományos vallásos attribútumokat használó versek mellett olyanokat is találunk a kötetben, melyek nem feltételezik a vallásos kultúra meglétét, a Biblia történeteinek és fogalomrendszerének ismerete nélkül is befogadhatóak." (Pompor 2009, 23)

Tanulmányunk szempontjából még érdekesebb Miklya másik könyve. A Pityu azt mondja... egy gyermek - Pityu kistestvére - nyílt és határtalan kíváncsiságának, valamint a báty végletekig őszinte megnyilatkozásainak gyűjteménye. Egy olyan fiúé, aki nemcsak keresi Istent, de beszél is az ezzel kapcsolatos élményeiről éppúgy, ahogy a kétségeiről is. „Miklya Zsolt korábbi kötetéhez hasonlóan ezek a versek is a tradicionális vallásosság kellékei nélkül a gyermek szemléletével és szókincsével kérdeznek Istenről. Isten hol lakik? Szereti-e az állatokat? És az embereket? Mindenkit? Melyik a kedvenc színe? Szokott-e 
fürdeni? Szokott-e játszani? Olyan kérdések ezek, amelyek éppúgy lehetnek a vallásos tradícióban cseperedő gyermek kérdései, mint a más kulturális háttérrel rendelkező kiskamaszé, aki a lét alapvető kérdéseire keresi a választ." (Pompor 2009, 24-25)

Két példa a kötetből:

\section{Isten mindenkit szeret}

Isten mindenkit szeret?

A nénit is, aki az aluljáróban ül és kéreget?

Szilárdot is, akit a tanító néni mindig kiküld az osztályból, és a szünetben verekszik?

A bibliában az van, hogy Jézus

a bűnösök barátja meg a szegényeké.

Jó, Jézusról ezt el tudom képzelni, de én Istenre lennék kíváncsi.

Ő leengedne Szilárddal focizni a játszótérre?

Pityu szerint már a kérdés is hülye.

Ő Isten helyében szóba se állna az ilyenekkel.

Lehet, hogy igaza van,

de most meg az jutott az eszembe,

mit tenne Isten a Pityu helyében.

Vagy mondjuk az enyémben.

\section{Isten szereti az állatokat}

Ugye te is szereted az állatokat?

Nekünk van egy macskánk, úgy hívják, hogy Murminc.

Anya először nem akarta, azt mondta, fertőz, meg hullik a szőre.

De apa megvédte. Elvittük az állatorvoshoz.

Pityu persze inkább kutyát szeretne, de ahhoz kicsi az udvar.

Ezt nem egészen értem.

Az ékszerteknősöknek mért nem kicsi akkor

az akvárium?

A tévéből hallottam, hogy a Föld is kicsi.

Kinőttük.

Isten majd biztosan kicseréli nagyobbra.

Mert ő szereti az állatokat.

Meg az embereket is.

Igazi svéd típusú gyerekköltészet ez, ami nem csupán annyit jelent, hogy mentes a formai kötöttségektől, de azt is, hogy a nyíltság, a szókimondás mellett alapeleme a humor is. Ráadásul a didaxisnak nyomát sem látjuk, a szerző inkább csak felveti a kérdéseket, nem akar azokra választ adni. Mindez különösen érdekes Miklya Zsolt költészetét ismerve - a formákat jól használó, a rímes, ritmusos lírában otthonosan mozgó, a költői képeket kifejezetten bátran, gyakran használó alkotóról van szó. Ehhez képest ez a műfaj komoly kötöttséget is jelenthetett volna számára, de azt látjuk, hogy jól érezte magát az „új szabályok” adta keretek között is. Sőt, nem csupán jól alkalmazkodott ezekhez, de egy egyéni hangot is meg tudott szólaltatni. (Csak részben mellékes a megjegyzésem: bár 
egyre többen felfedezik, Miklya Zsolt a kortárs gyermekirodalom súlyosan alulértékelt alkotói között van.)

Természetesen további írók munkáját is idézhetném, elemezhetném, Miklya Luzsányi Mónikától Lázár Ervinen át Szecsődi Leóig. A választék valójában nem túl gazdag, nem nagyon lehetne bármilyen szempont alapján csoportosítani a szerzőket - már mennyiségi okokból sem... Egy költőt és egy verset azonban kiemelnék még, már csak azért is, mert ez a szöveg - amellett, hogy több szempontból is figyelemre méltó - jól megmutatja, milyen harmonikus egységben lehet humor és mélység, a gyermeki világlátás egyszerűsége és a világmegváltó gondolatok. Lackfi János sosem tagadta hitét, ezzel együtt nem „keresztény költőként" tartják, tartjuk számon, noha számtalan versben tett már tanúságot. (A miértre talán nem olyan bonyolult a válasz: Lackfi életműve fiatal kora ellenére is kifejezetten gazdag és színes, ezen belül nem döntő ezen müvek aránya.)

A Világ vége című vers egyszerre él a svéd gyerekvers eszközeivel (homodiegetikus elbeszélés, gyermeki látásmód, szókimondás) és a Lackfira jellemző bátorsággal a témaválasztást és a megfogalmazást illetően. S nem utolsósorban: a kötetlen forma mellett is azt érezzük, igazi költészet ez...

\section{Világ vége}

Gerő mondta, hogy a múltkor

egy utcában, ahol már

a város véget ér,

és kezdődik az erdő,

az aszfaltból meg földút lesz

egyszeriben,

és ahol már időnként

rókát meg fácánt látni,

szóval ott van egy kő,

és azon a kövön, de pszt,

el ne áruljam senkinek,

múltkor látta ülni az Istent.

Nem csinált semmit, csak ült,

hát gondolhatod,

hogy rohadt fáradt lehet,

az idő kezdete óta babrálni

evvel az egész tetves világgal,

mindenkinek a vacak problémáival

meg karácsonyi vágyaival

meg szerelmeivel,

elég az osztályunkat hallgatni,

besokall az ember.

Én lehet, hogy rég

földhöz vágtam volna az egészet,

csak úgy csörömpölne,

gurulnának a darabjai százfelé.

Aztán felállt az Isten,

sóhajtott és elballagott,

és ennyi, de titok.

Nem mertem megkérdezni

a Gerőtől, hol volt ez pontosan, 
hátha az is titok,

de egyszer elmentem a busszal

a végállomásig,

kimentem az utolsó utca végére,

tényleg volt ott egy kő,

szerintem pont ugyanaz,

mert leültem rá,

és tényleg úgy éreztem,

ez itt a világ legszéle, és hirtelen

olyan baromi fáradt lettem,

mint az Isten.

Nem könnyű egyfajta összegzést adni akkor, amikor inkább elméleti fejtegetésbe bocsátkoztam, inkább meghatározásokat próbáltam adni a keresztény gyermekirodalom kapcsán. Igaz, ennek az is az oka, hogy a témán belül - különösen magyar szerzőket figyelembe véve - nincs annyiféle műfaj, s arányaiban a művek száma sem jelentős. Hogy mégsem érzem indokolatlannak magát a témafelvetést, az elsősorban az elmúlt évtizedek, évek tapasztalatainak köszönhető. Miközben az indulás kifejezetten nehéz volt - az irodalmi értékek sokáig maximum „átsejlettek” a didaktikus szövegek mögül -, a jelen több mint biztató. A keresztény gyermekirodalom „fejlődése” mintha párhuzamosan, együtt menne a gyermekirodalom haladásával. És az megkérdőjelezhetetlen, hogy a műfajban a humornak is bőven van helye, szerepe, létjogosultsága.

\section{Irodalom}

Alker, R. K. (2019): Funny Kids Christian Books - Writing Humorous Christian Fiction for Tweens and Teens. [online] [2021. 03. 12.] <URL: https://rkalker.com/2019/12/13/ funny-kids-christian-books-writing-humorous-christian-fiction-for-tweens-and-teens / Drescher Pál (1934): Régi magyar gyermekkönyvek. Bp.: Magyar Bibliophil Társaság [online] [2021. 02. 23.] <URL: https://mek.oszk.hu/03100/03165/html/

Esterházy Péter (2003): A szavak csodálatos életéből. Bp.: Magvető Komáromi Gabriella szerk. (1999): Gyermekirodalom. Bp.: Helikon Kormos István (1982): A vasmozsár törôje alatt. Bp.: Szépirodalmi Miklya Zsolt (2009): „Egy állig gombolkozott angyal” : Keresztyén gyermekkönyvekről szerzői szemszögből. Református Nevelés, 10(3), 18-20.

Pompor Zoltán (2009): Tradíció és kultúra összjátéka mai magyar keresztyén gyermekkönyvekben. Református Nevelés, 10(3), 21-28.

\section{SUMMARY}

\section{Christian children's literature and humour}

While I am presenting specific authors and, what is more, texts in my study, basically I raise theoretical questions and try to answer them.

What is Christian literature? What is Christian children's literature? Does or can didacticism have a place in (Christian) children's literature? Does humour have a reason for existing in Christian literature?

After the clarification of the notions and fundamental questions I have not attempted to categorize or group the works considered appropriate. Most of all, because there are not so 
many genres within the topic - especially taking into consideration the Hungarian authors - and the number of works is proportionally not significant to be relevant. I do not consider the raising of the issue to be groundless though, which is mainly due to the observations of the past decades. While the start was specifically difficult - the literary values had only some "transparency" for a long time from behind the didactic texts -, the present is more than promising. It seems as if the "development” of Christian children's literature went side by side, together with the advancement of children's literature.

Keywords: children's literature, Christian literature, humour 